\title{
The south-western Black Forest and the Upper Rhine Graben Main Border Fault: thermal history and hydrothermal fluid flow
}

\author{
H. Dresmann $\cdot$ N. Keulen $\cdot$ Z. Timar-Geng $\cdot$ \\ B. Fügenschuh $\cdot$ A. Wetzel $\cdot$ H. Stünitz
}

Received: 8 March 2007/Accepted: 2 November 2008/Published online: 27 November 2008

(C) Springer-Verlag 2008

\begin{abstract}
The thermal history of the south-westernmost Black Forest (Germany) and the adjacent Upper Rhine Graben were constrained by a combination of apatite and zircon fission-track (FT) and microstructural analyses. After intrusion of Palaeozoic granitic plutons in the Black Forest, the thermal regime of the studied area re-equilibrated during the Late Permian and the Mesozoic, interrupted by enhanced hydrothermal activity during the Jurassic. At the eastern flank of the Upper Rhine Graben along the Main Border Fault the analysed samples show microstructural characteristics related to repeated tectonic and hydrothermal activities. The integration of
\end{abstract}

H. Dresmann $(\bowtie) \cdot$ N. Keulen · A. Wetzel $\cdot$ H. Stünitz Geologisch-Paläontologisches Institut, Universität Basel, Bernoullistrasse 32, 4056 Basel, Switzerland

e-mail: horst.dresmann@unibas.ch

Present Address:

N. Keulen

GEUS, Øster Voldgade 10, 1350 Copenhagen, Denmark

Present Address:

H. Stünitz

Institutt for Geologi, Universitetet i Tromsø, Dramsveien 210,

9037 Troms $\varnothing$, Norway

Z. Timar-Geng

Geologisches Institut, Albert-Ludwigs-Universität Freiburg,

Albertstr. 23b, 79104 Freiburg, Germany

Present Address:

Z. Timar-Geng

Geoenergie Bayern GmbH, Schwandorfer-Str. 12,

93059 Regensburg, Germany

B. Fügenschuh

Institut für Geologie und Paläontologie, Universität Innsbruck, Innrain 52, 6020 Innsbruck, Austria microstructural observations of the cataclastic fault gouge with the FT data identifies the existence of repeated tectonic-related fluid flow events characterised by different thermal conditions. The older took place during the Variscan and/or Mesozoic time at temperatures lower than $280^{\circ} \mathrm{C}$, whereas the younger was probably contemporary with the Cenozoic rifting of the Upper Rhine Graben at temperatures not higher than $150^{\circ} \mathrm{C}$.

Keywords Black Forest - Upper Rhine Graben Border Fault · Fission-track analysis - Microstructures . Hydrothermal fluid flow . Thermal history .

Brittle deformation

\section{Introduction}

In the light of the enhanced interest on new regenerative energy sources, several geothermal projects were targeted on the Upper Rhine Graben (URG) between Frankfurt (Germany) and Basel (Switzerland). Especially, thermal anomalies and the distribution of subsurface fluid pathways and their temperatures are of growing importance for the geothermal energy projects. These subsurface fluid flow regimes are the main factors influencing the thermal regime of a region. The understanding of the thermal history of the graben flanks, especially along the escarpments and their surroundings, is crucial for the understanding of the thermal regimes within the graben, as it was already suggested by previous authors (e.g. Lampe and Person 2002; Giersch 2006; Rybach 2007).

Faults play a major role as pathways for hydrothermal activity and may lead to locally elevated temperatures in their vicinity. Thermal springs and hydrothermal ore deposits are often related to such structural discontinuities 
(e.g. Sibson 1990). In the URG, several thermal anomalies, which are well-known features in active rift systems, have been identified (e.g. Haas and Hoffmann 1929; Werner and Doebl 1974; Teichmüller 1979; Person and Garven 1992; Schellschmidt and Clauser 1996; Lampe and Person 2002).

While the thermal history of the central southern Black Forest (i.e. the eastern graben flank) was already investigated by fission-track (FT) analysis (Timar-Geng et al. 2004, 2006), the south-westernmost Black Forest has not been studied in detail until now.

To better constrain the thermal evolution of the southwestern Black Forest and the adjacent URG Main Border Fault fission-track (FT) thermochronology was applied (e.g. Tagami and O'Sullivan 2005). Furthermore, to characterise the former hydrothermal fluid flow along the URG Main Border Fault, the FT data were integrated with detailed microstructural analyses of cataclastic rocks.

Fission-track analysis of apatite and zircon grains potentially constrains the host rock thermal history of shallow crustal levels below temperatures of about $380^{\circ} \mathrm{C}$. Experimental studies and in-situ borehole observations indicate partial annealing zones (PAZ) of apatite (APAZ) between about 110 and $60^{\circ} \mathrm{C}$ (e.g. Gleadow and Duddy 1981) and for zircon (ZPAZ) between 380 and $180^{\circ} \mathrm{C}$, respectively (Tagami 2005 and references therein). Additionally, these temperatures cover a large part of the temperature range that is typically reported for hydrothermal fluids. In distinct cases, the FT method could be an appropriate tool to understand the timing of hydrothermal activity, as shown in a few FT studies (e.g. Jelinek et al. 1999; Parry et al. 2001; Timar-Geng et al. 2004, 2008).

Microstructural investigations of thin sections of the FTsamples provide further insight into the deformation regime, the relative age of tectonic movements, the syndeformational temperature and the presence and chemistry of fluids during or shortly after deformation. The combination of the FT method and microstructural investigations forms a good tool to get a better knowledge on the history of a fault zone in comparison to the regional thermal evolution, as it will be shown here on the example of the south-eastern URG Main Border Fault.

\section{Geological framework}

The study area is situated in SW Germany between the Black Forest, the URG and the associated Dinkelberg Block. East of the village Kandern at the south-eastern side of the URG, a road cut exposes the junction of the NNEtrending and nearly vertical eastern URG Main Border Fault with the WNW-ESE striking Kandern-Hausen Fault (Fig. 1). Both fault systems were already active during the Variscan orogeny (Metz and Rein 1957; Illies 1967;
Echtler and Chauvet 1992). The outcropping granite is intensely deformed and displays substantial cataclasis, joints and discrete fault planes. Cataclasis and silicate veins indicate that pathways allowing for the ascent of fluids were formed.

The Kandern-Hausen Fault separates the Black Forest from the Dinkelberg Block, which takes an intermediate tectonic position between the Black Forest and the URG in the west. Here, Triassic and Jurassic strata are still preserved on top of at least $100 \mathrm{~m}$ thick Upper Permian sediments. The Kandern-Hausen Fault formed during the Palaeozoic as a dextral transtensive normal fault (Wirth 1984) and has been reactivated during the formation of the URG. Near Kandern along a steeply SSW-dipping fault plane a post-Mesozoic vertical displacement of about $450 \mathrm{~m}$ has been estimated (Wilser 1914). However, since no marker horizon is available on the hanging wall, this value bears some uncertainty. A vertical displacement of ca. 1,500 $\mathrm{m}$ was estimated along the URG Main Border Fault between the Dinkelberg Block and the URG (Gürler et al. 1987). Towards the graben interior the Main Border Fault is accompanied by a complex set of structures, which form a step-like escarpment and accommodate further graben subsidence. In the following, the junction of the Main Border Fault with the Kandern-Hausen Fault is called "Kandern Fault Zone".

The basement rocks today exposed in the southern Black Forest have been affected by regional metamorphism, large-scale thrust tectonics and extensive magmatic activity during the Variscan orogeny (e.g. Eisbacher et al. 1989; Echtler and Chauvet 1992; Hann and Sawatzki 2000). At the end of the Variscan orogeny numerous intramontane basins were formed, as for example the so-called PermoCarboniferous Basin of Northern Switzerland (e.g. Thury et al. 1994). During the Mesozoic, thermal subsidence accompanied by subordinate crustal extension led to the deposition of several hundreds of metres of continental and shallow marine sediments (e.g. Geyer and Gwinner 1991; Wetzel and Allia 2003; Ziegler and Dèzes 2005). The opening of the URG during the Cenozoic was related to the changes in the stress field and reactivation of pre-existing Palaeozoic structures (e.g. Schumacher 2002; Hinsken et al. 2007). Mid-Eocene fresh-water limestones are the first indicators for the onset of subsidence in the URG area (e.g. Berger et al. 2005a, b). Furthermore, the EoceneOligocene alluvial fan deposits along the basin margins indicate an increasing relief and erosion of the rift flanks (Duringer 1988; Hinsken et al. 2007). In the southern URG, Upper Oligocene to Miocene strata were largely eroded due to Miocene regional uplift (e.g. Laubscher 1987; Ziegler 1994; Sissingh 1998; Berger et al. 2005a, b) simultaneously with the uplift of the graben flanks (Vosges and Black Forest). 


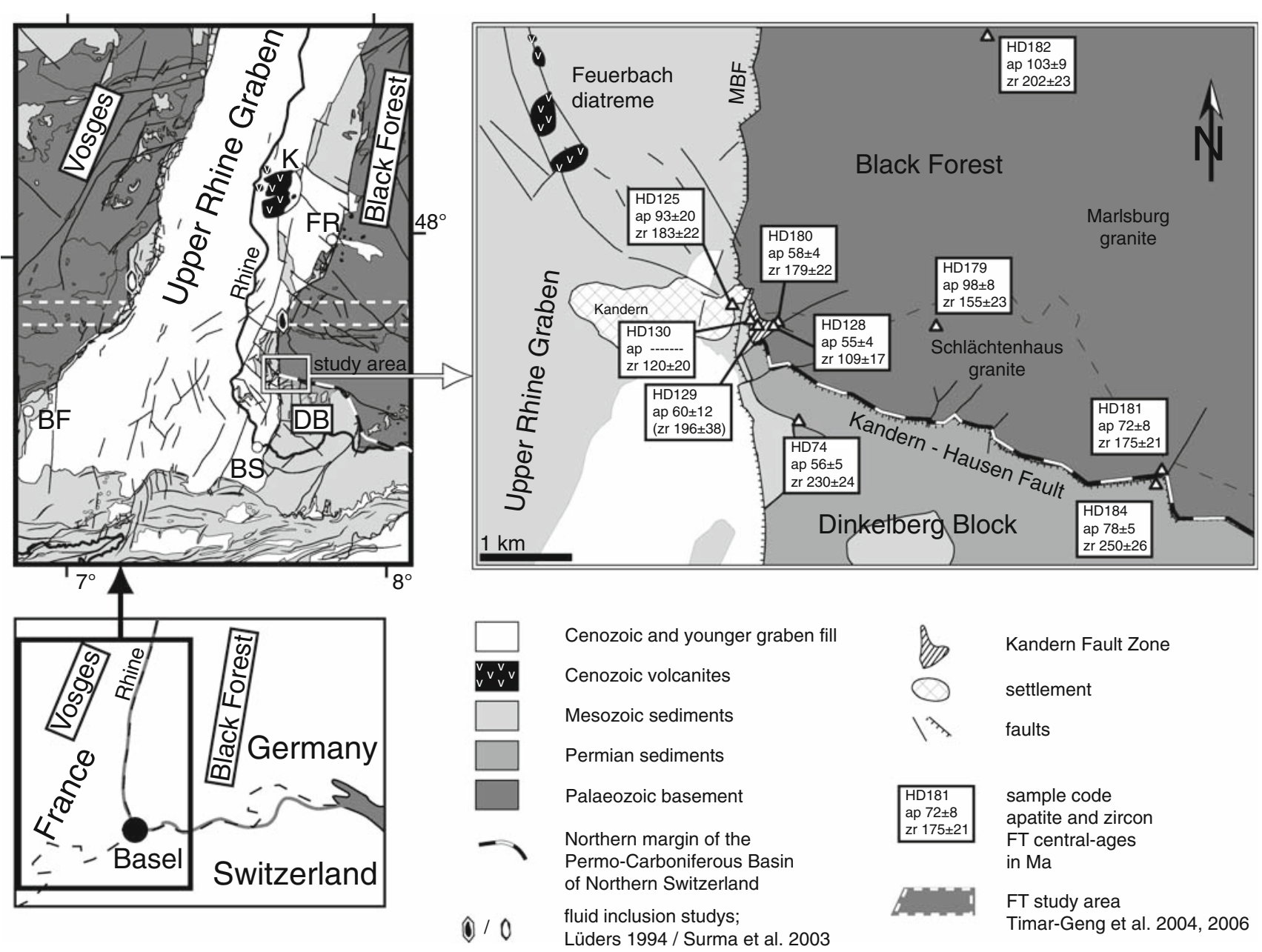

Fig. 1 Geological map of the study area (modified after Metz and Rein 1957; Schnarrenberger 1985; Chantraine et al. 1996; Ernst and Hergesell 1997; Ustaszewski et al. 2005). $D B$ Dinkelberg Block, $B F$ Belfort, $B S$ Basel, $F R$ Freiburg, $M B F$ Main Border Fault, $K$ Kaiserstuhl volcano

The thermal history of the southern Black Forest is well documented by FT data along an E-W profile (Fig. 1) through the central southern Black Forest (Timar-Geng et al. 2004, 2006). After the emplacement of granitic plutons during Variscan times slow cooling of the upper crust dominated. Extensive hydrothermal activity with temperatures of $\sim 250^{\circ} \mathrm{C}$ during the Jurassic caused substantial overprint of the inherited apatite and zircon FT ages (Timar-Geng et al. 2004, 2006). A moderate cooling below $120^{\circ} \mathrm{C}$ affected the uppermost crystalline basement of the Black Forest between Jurassic and Late Eocene times, followed by a short heating event with temperature of up to $120^{\circ} \mathrm{C}$ coeval with enhanced subsidence of the URG during the Late Eocene to Early Oligocene (Timar-Geng et al. 2006). Although the rocks generally cooled since then the exact thermal conditions during the Miocene are still a matter of debate (Timar-Geng et al. 2006, Ziegler and Dèzes 2007).

Regional studies such as dating of ore mineralisations (e.g. Werner and Franzke 2001) along faults within the
Black Forest provide data on the timing of hydrothermal activity and document several distinct phases between the Triassic and the Cretaceous (e.g. Wetzel et al. 2003). Additionally, some fluid inclusion data from the eastern and western URG Main Border Fault display fluid flow with temperatures of up to $225^{\circ} \mathrm{C}$ related to tectonic activity (Fig. 1; Lüders 1994; Surma et al. 2003). These hot fluid migrations are on the one hand dated as Cenozoic (Lüders 1994) and on the other hand a Mesozoic age is also possible (Surma et al. 2003).

The thermal evolution of the study area east of Kandern after the Variscan emplacement of the Marlsburg-Granite (329 \pm 3 Ma; Todt 1976) and the Schlächtenhaus-Granite (334 $\pm 2 \mathrm{Ma}$; Schaltegger 2000) is only roughly known and can be extrapolated from the FT data from the central southern Black Forest (Timar-Geng et al. 2004, 2006).

Interestingly some faults geometrically connect the Feuerbach diatreme, located $\sim 2.5 \mathrm{~km} \mathrm{NW}$ of Kandern, with the Kandern Fault Zone (Fig. 1). Although the Feuerbach diatreme has never been dated directly, 
mineralogical and petrographical similarities between this diatreme and the Kaiserstuhl (Fig. 1) volcanism suggest a Cenozoic age (Schreiner et al. 1957). Therefore, it is the southernmost evidence of rift volcanism in the URG. Its relevance for the thermal regime at the Kandern Fault Zone is still unknown.

\section{Samples, methods and results}

Seven samples of the Black Forest crystalline basement were taken from the Schlächtenhaus- and Marlsburggranite in the south-western Black Forest (Fig. 1). Four samples represent undeformed granites (HD179, HD180, HD181, HD182) and two samples (HD129, HD130) are cataclasites with their adjacent wall-rock from the Kandern Fault Zone. The cataclasites are associated with a NNE-SSW striking fault set, which forms part of the several metre thick URG Main Border Fault. A nearly undeformed granite (HD128) has been collected some $100 \mathrm{~m}$ east of the cataclasite sample location. It originates directly from a subordinate fault plane, which strikes parallel (WNW-ESE) to the Kandern-Hausen Fault (Fig. 1). Two samples (HD74, HD184) from the Upper Permian sedimentary rocks (deposition age 251-272 Ma) of the Dinkelberg Block and one sample (HD125) from the Lower Jurassic sedimentary rocks (deposition age 178-184 Ma) within the stepwise faulted graben margin at Kandern complete the sample set (Fig. 1).

\section{Fission-track analysis}

Fission-track analysis on apatite and zircon was carried out applying the external detector method according to Naeser (1976) and Gleadow (1981) (see Appendix for details). Ten samples yielded 9 apatite and 10 zircon FT ages. All ages are reported as central ages (Galbraith and Laslett 1993). Results are given in Table 1 and Fig. 2.

Zircon ages range between $109 \pm 17$ and $250 \pm 26 \mathrm{Ma}$ (Table 1; Fig. 2). The zircon FT ages of the detrital samples HD074, HD125 and HD184 do not differ significantly from their deposition ages within error. The fault related samples yielded the youngest ages of $109 \pm 17 \mathrm{Ma}$ (HD128) and $120 \pm 20 \mathrm{Ma}$ (HD130). Yet, due to a relatively strong zonation and metamictization, only a limited number of zircon grains could be analysed.

The apatite samples yielded ages ranging from $55 \pm 4$ to $103 \pm 9 \mathrm{Ma}$ (Table 1; Fig 2). The majority of the apatite grains were of good quality but the low track density did not allow for statistically reliable track length measurements. Only in sample HD128 a total of 17 confined horizontal tracks could be measured yielding a mean track length of $10.5 \mu \mathrm{m}$. Yet also this sample has not been used for thermal modelling.

All samples from the sedimentary rocks yield apatite FT ages younger than their deposition ages, indicating that they have experienced certain amount of annealing due to thermal heating after their deposition.

Several zircon and apatite FT samples fail the $\chi^{2}$-test, which implies that their central ages represent a mixture of more than one age population (Table 1). The large spread in single grain ages (Fig. 2) is probably related to the different annealing kinetics of the individual grains. The distinct annealing behaviour is probably related to variable amounts of accumulated $\alpha$-damage and/or compositional variations (Green et al. 1985; Kasuya and Naeser 1988; Brandon et al. 1998).

\section{Microstructural analysis}

Thin sections of granitoid cataclasites were made for optical and scanning electron microscope (LM and SEM) studies. The samples originate from the same localities as the FT samples HD129 and HD130. Additionally, cathodoluminescence (CL) was studied on a light microscope connected to a CL-camera using $25 \mathrm{kV}$ acceleration voltage and 0.025 mA sample current (Ramseyer et al. 1989).

Two cataclastic deformation episodes can be distinguished for the NNE-SSW-striking faults of the Kandern Fault Zone. Evidence for the older episode (Cataclasite-I) are large, multi-component clasts, which have been healed and cemented before the formation of a younger cataclasite (Cataclasite-II; Fig. 3). In Cataclasite-I, quartz and feldspar are fractured (Fig. 3). Quartz and feldspar clasts in discrete fractures are completely healed and have lost their angular shapes (Fig. 3c, d). Instead, they appear as well-rounded (recrystallized) grains. Some healed cracks reveal structures indicative of bulging recrystallization (Fig. 3c, d; Stipp et al. 2002a, b), but other observations indicating substantial crystal plastic deformation are missing. Kinking and gliding along (001) planes is observed in deformed biotite at the edges of Cataclasite-I clasts. After formation of Cataclasite-I, a set of thin barite veins formed (Fig. 3b).

Cataclasite-II is characterised by fragmented and granulated quartz, feldspar, biotite, muscovite, hematite, and multi-component fragments originating from Cataclasite-I, all of them forming fine-grained matrix. All minerals show only brittle deformation features. Cataclasite-II forms clasts ranging from less than $1 \mu \mathrm{m}$ to about $10-20 \mathrm{~mm}$ in cross-section (Fig. 3a, b). The observed average size of the quartz fragments is slightly larger than for feldspar; most of the larger clasts are quartz minerals.

A series of syntaxial silicate veins cuts through all other structures. The silica-rich veins consist of adularia when 


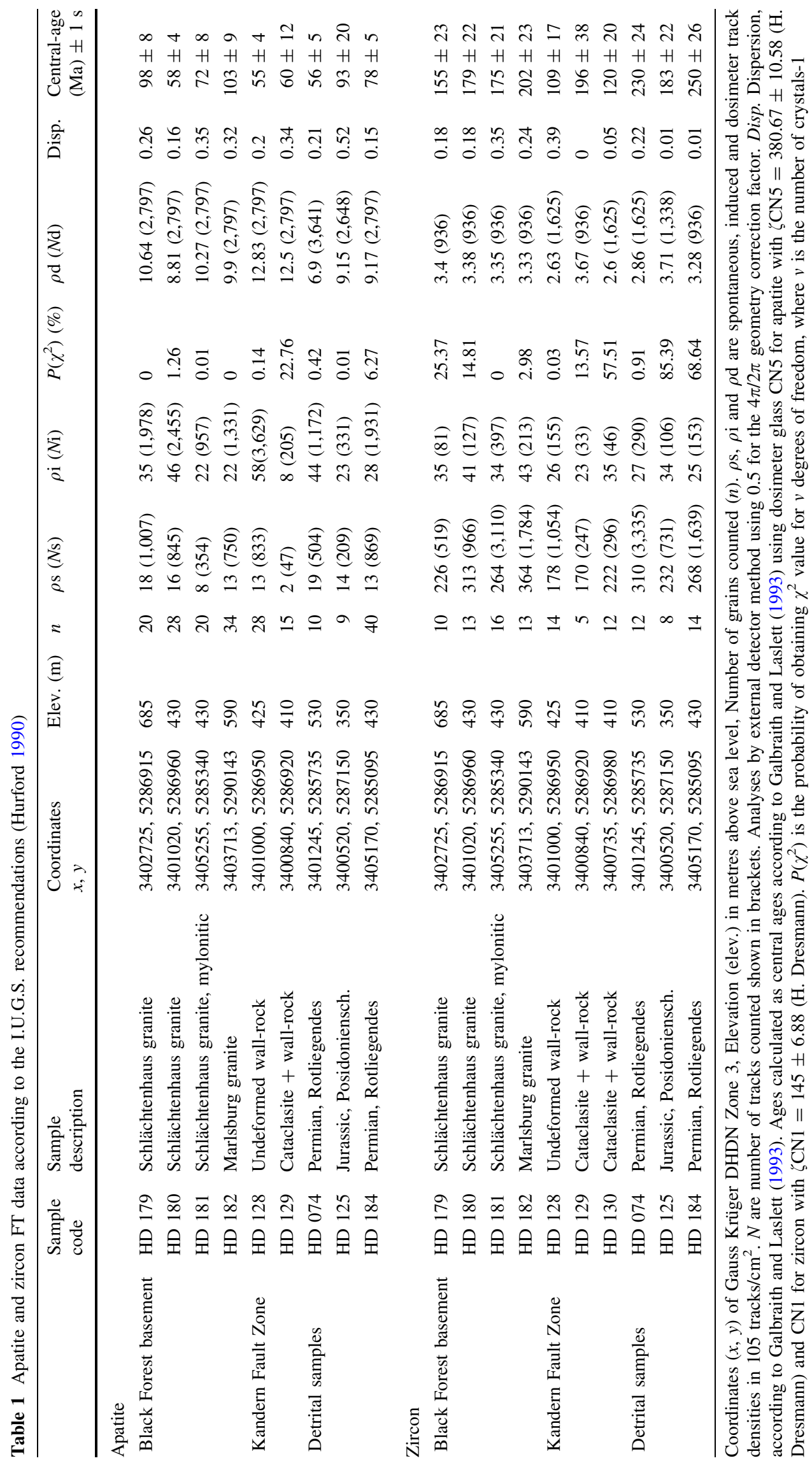




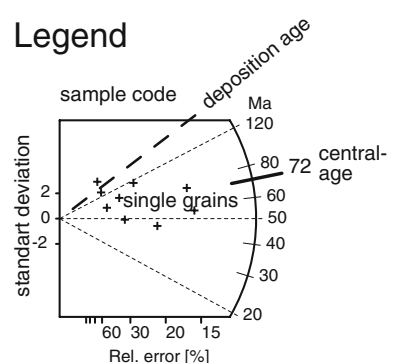

sediments
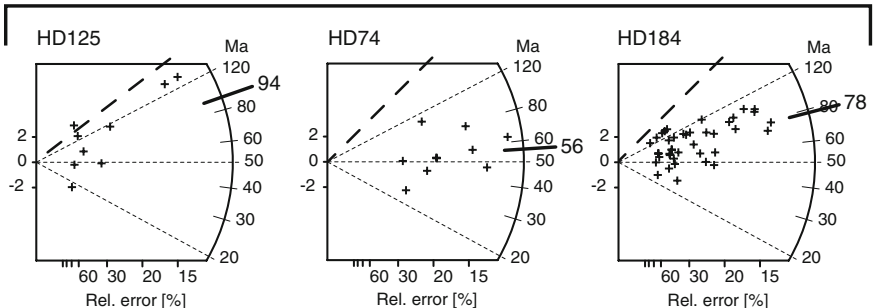

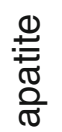

basement
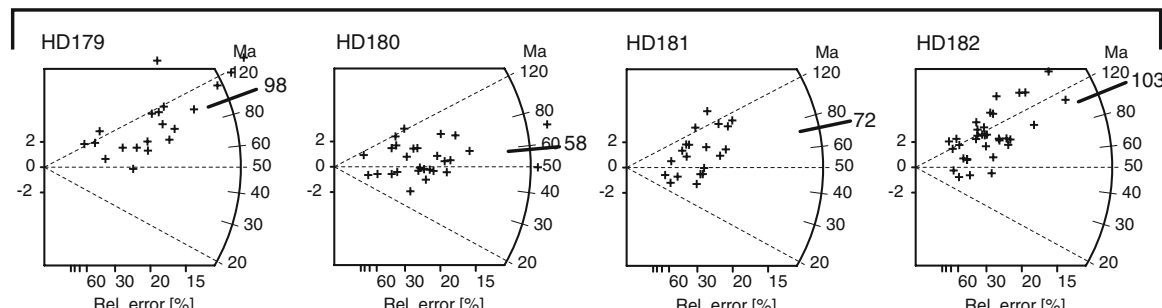

Rel. error [\%]
Kandern Fault Zone / cataclasite + wall-rock

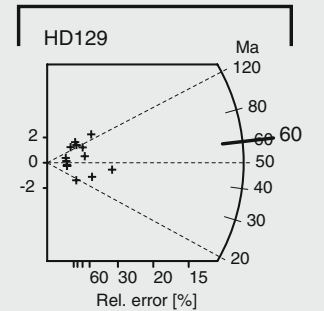

Kandern Fault Zone / undeformed wall-rock

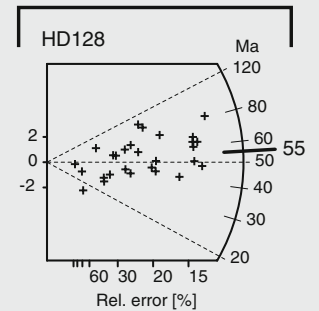

sediments
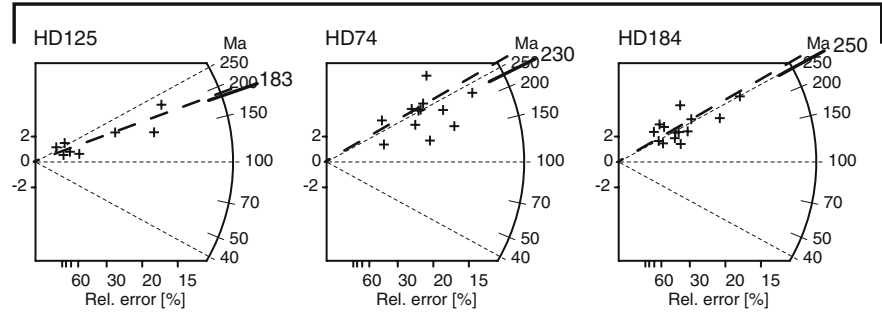

음
늠

\section{basement}
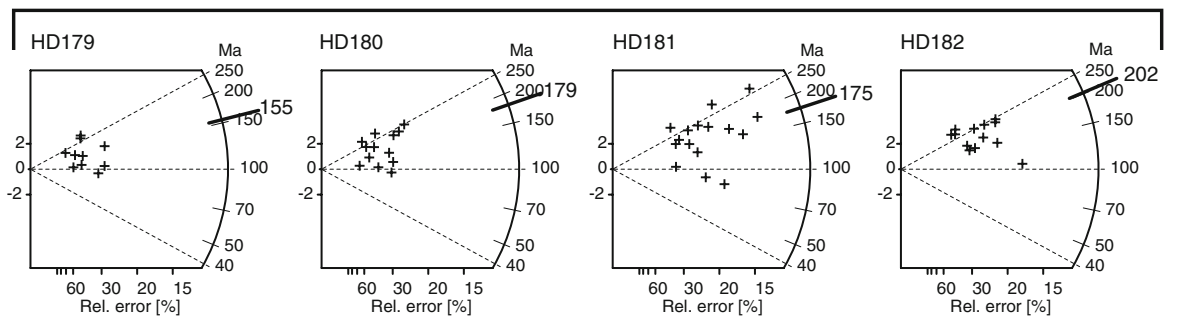

Kandern Fault Zone / cataclasite + wall-rock

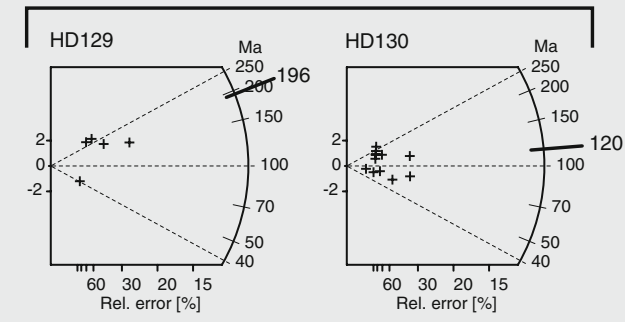

Kandern Fault Zone / undeformed wall-rock

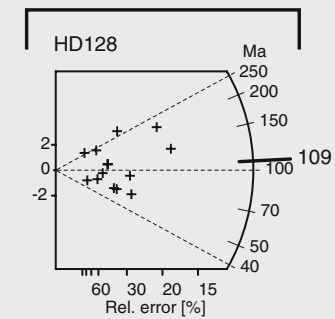

Fig. 2 Apatite and zircon FT radial plots (Galbraith 1988, 1990) of the Kandern area sample set including the samples of the Kandern Fault Zone (shaded). The FT ages and errors were calculated using the software Trackkey (Dunkl 2002)

cutting through K-feldspar and of quartz within quartz or plagioclase minerals. By means of cathodoluminescence two generations of silicate deposition have been observed. The first one cements fractures in quartz, plagioclase and K-feldspar with luminescent material of the same phase (Fig. 4a). The closed fractures have the same optical orientation as the minerals in which the fractures occur and are hardly visible with LM or SEM (BSE contrast). The second generation is represented by the earlier described late silicate veins, and is low-luminescent (Fig. 4b). The change from quartz deposition to adularia deposition can be observed as a colour change of the vein material from black to dark grey (Fig. 4b).

To obtain the grain size distribution of the cataclasites several sets of back-scattered electron contrast SEM micrographs with a range of magnifications from $50 \times$ to $5,000 \times$ were used. After manually tracing the grain boundaries in each of the individual images the grain areas 
Fig. 3 Backscatter-contrast scanning electron micrographs (a, b) and crossed polarised light $(\mathbf{c}, \mathbf{d})$ showing typical microstructures from the Kandern Fault zone. a Cataclasite-II, in which larger clasts consist of fractured and re-cemented clasts (CataclasiteI); b thin barite veins (white, arrows) cut Cataclasite-I and do not continue into the matrix of Cataclasite-II. KFS K-feldspar, $Q T Z$ quartz, $P L G$ plagioclase; (c, d) along a healed crack quartz has been deformed by bulging recrystallisation (arrows)
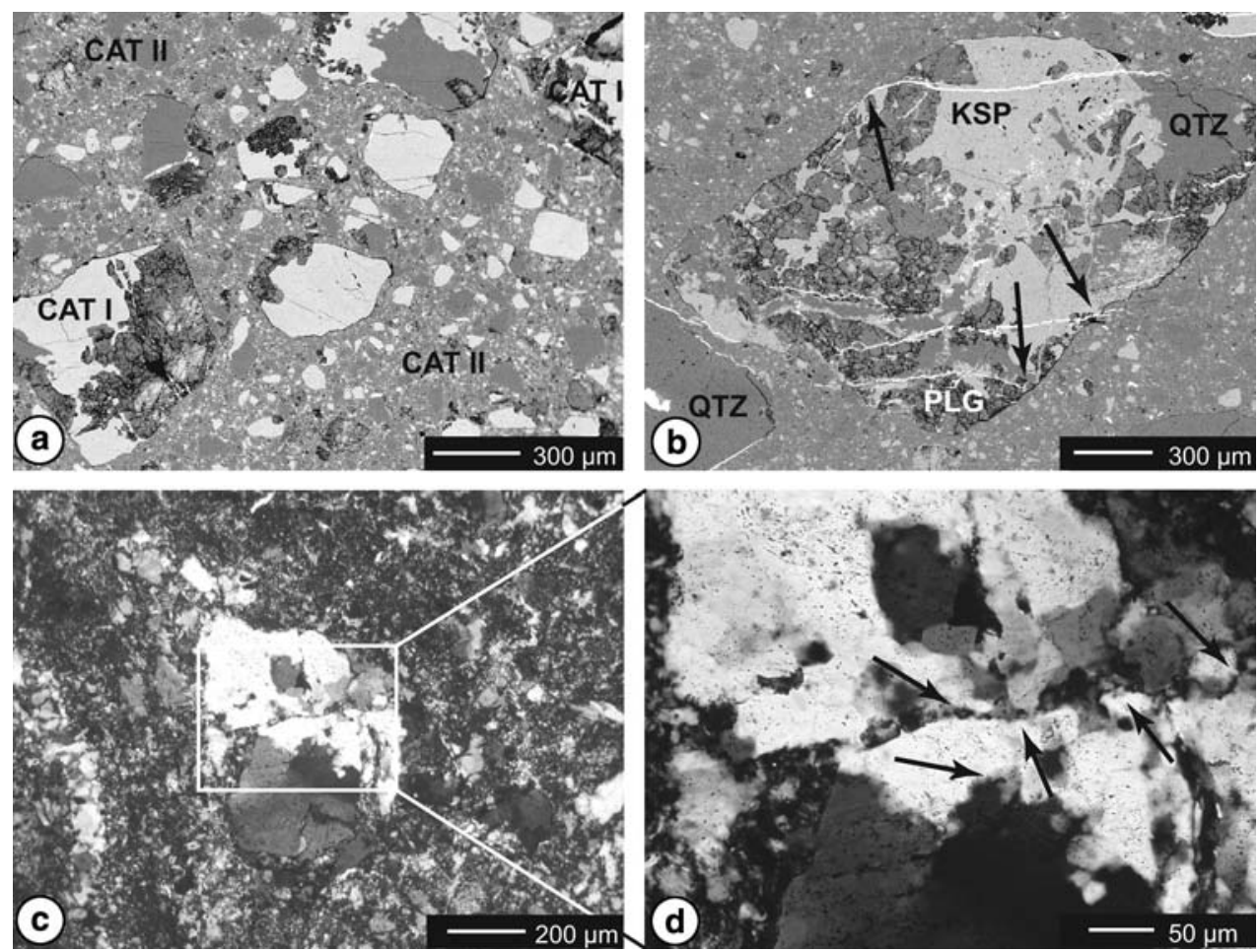

were measured automatically with help of the public domain software ImageSXM (http://www.liv.ac.uk/ sdb/ ImageSXM/) and recalculated to radii of their equivalent circles. By combining the analyses of the individual images a composite grain-size distribution over several orders of magnitude can be obtained, described as a log (frequency) - log (size) histogram (Keulen et al. 2007). The slope $D$ of the best-fit power-law curve through the points in this histogram represents the grain-size distribution of the fault gouge (Sammis et al. 1987). Post-fracture healing of cataclasites reduces the relative amount of small grains with respect to large grains and causes a decrease in the $D$-value. The decrease in $D$ values may provide a measure for the consolidation of the cataclasite (Keulen et al. 2008).

The grain size distribution fits on a straight line in the $\log$ (frequency) $-\log$ (size) histogram $(D$ value $=1.58)$. The minimum measured grain size has a radius of $1 \mu \mathrm{m}$ and is the smallest grain size present with a statistically relevant resolution. The largest measured grain size is limited by the size of the thin section and is not the largest size of fragments in the rock.

\section{Interpretation and discussion}

Our zircon FT data from the Kandern area (central FT ages between $109 \pm 17$ and $250 \pm 26 \mathrm{Ma}$ ) are compatible with the dataset of Timar-Geng et al. (2004, 2006) (Fig. 5), who reported zircon FT central ages ranging between $136 \pm 16$ and $312 \pm 29 \mathrm{Ma}$. Barring the detrital samples theses values are younger than the formation ages of the analysed samples suggesting that these rocks have experienced thermal overprint, at temperatures higher than the lower temperature boundary of the zircon partial annealing zone (ZPAZ), during the Mesozoic or later. The broad distribution of the single grain ages, as seen on the radial-plots (Fig. 2), and the heterogeneity of the $\chi^{2}$-test values reflect a complex thermal history, with probably more than one period of relative heating, or a long residence time for the samples within the ZPAZ. Timar-Geng et al. (2004) already suggested some thermal overprint in the basement of the Black Forest due to hydrothermal fluid activity during the Jurassic.

Estimation of the exact temperatures reached by the samples from the Kandern area during periods of reheating is a very difficult task. Tagami (2005) estimated the zircon partial annealing zone for natural zircons ranging between 380 and $180^{\circ} \mathrm{C}$. This estimation was made without quantification of damages of the crystal lattice by alpha-decay. The accumulation of radiation damages caused by alphadecay is an important factor influencing the temperature range of the ZPAZ which can substantially lower its temperature boundaries (Kasuya and Naeser 1988; Brandon et al. 1998). This is especially valid for samples, which were never heated up to temperatures exceeding the ZPAZ for a time allowing for total annealing (Rahn et al. 2004; Timar-Geng et al. 2004). Due to the fact that the zircon 


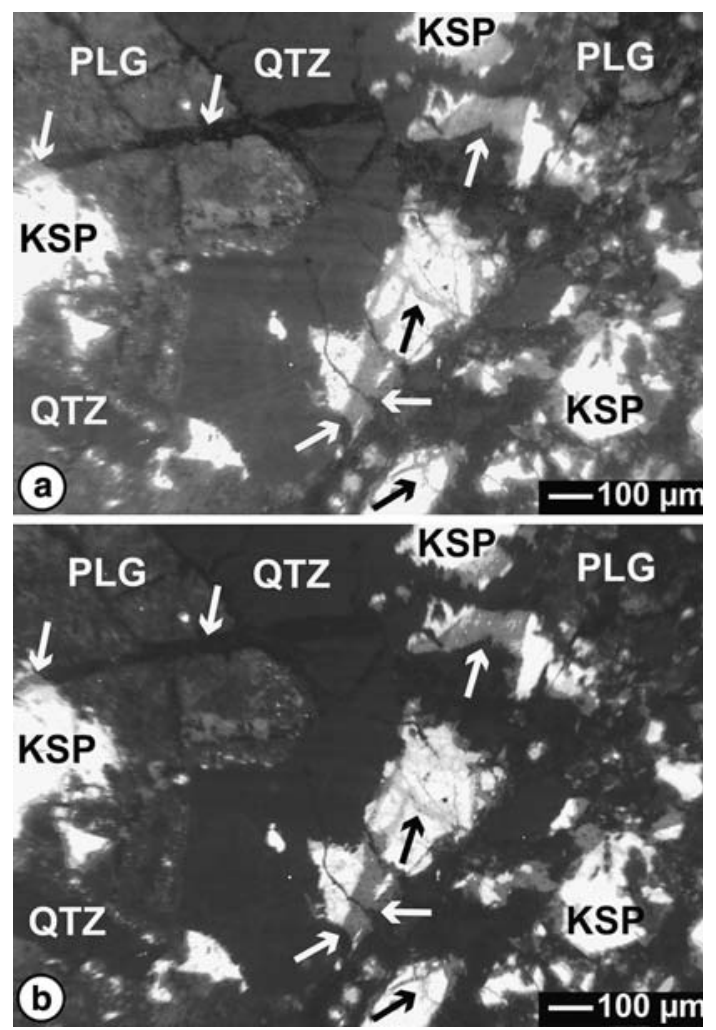

Fig. 4 Crossed polarised light and cathodoluminescence camera micrographs of structures in the Kandern Fault zone. a Equivalent image to (b) with adjusted (inverted squared) grey-values. a Clasts of Cataclasite-I (K-feldspar, white) cemented with light grey luminescent material (black arrows). Later fractures cut through all minerals and are cemented with low-luminescent (dark-grey/black) material, indicated in (b) with white arrows

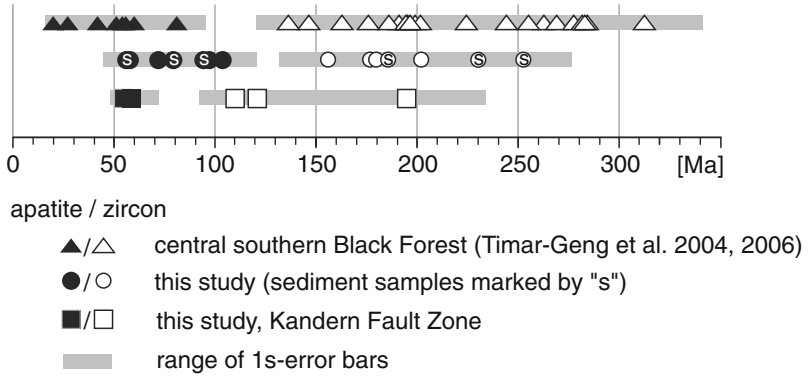

Fig. 5 Fission-track central-ages for apatite (black) and zircon (white) originating from Black Forest, Kandern area and the Kandern Fault Zone. Error bars (grey) indicate $1 \sigma$. The apatite FT central ages of the Kandern region are slightly older than the FT central ages for the central southern Black Forest (Timar-Geng et al. 2006). Zircon samples of the Kandern Fault Zone yield younger FT central-ages than the reference sample sets, while the apatite FT central-ages do not differ significantly from the other sample sets

samples from the Kandern area display a high degree of metamictization, most probably due to the alpha-decay, we assume that even temperatures below $180^{\circ} \mathrm{C}$ (ZPAZ boundary of Tagami 2005) could already cause some annealing of FTs in zircon.
Before we discuss the question concerning the heat source which affected the study area, we have to first evaluate the possible effect of burial on the analysed rocks. The estimations presented below are only minimum values for the eroded section above the sampled localities based on the approximate original thickness of the Mesozoic sediments and the eroded part of the Black Forest crystalline basement.

Although Permian sediments are still preserved not far from the studied area (Dinkelberg area, Fig.1) it is presumed that they were never deposited north of the Kandern-Hausen Fault, because this place was part of the northern border of the Permo-Carboniferous Basin of Northern Switzerland (Thury et al. 1994). The Otterbach II borehole, near Basel (Switzerland), is situated $\sim 15 \mathrm{~km}$ south of the studied area and comprises a nearly complete section of ca. 1,350 m of Triassic to Upper Jurassic sediments on top of the Palaeozoic units (Häring 2002). The section of the crystalline basement, eroded before the Mesozoic, at the sampled sites has been estimated of at least ca. 300-600 m, based on the present altitude of the outcrops beneath the mapped base of the Triassic palaeosurface in the Black Forest (e.g. Paul 1955; Zienert 1986; Wimmenauer and Schreiner 1990). Therefore, a minimum amount of overburden of about 1,650 to $1,950 \mathrm{~m}$ is suggested for the basement samples from the study area. This clearly indicates that, assuming a rather normal geothermal gradient of about $30^{\circ} \mathrm{C} / \mathrm{km}$, the burial alone cannot account for the temperatures experienced by the analysed samples.

The thermal history of the studied area is further constrained by apatite fission-track analysis. Our apatite FT ages, ranging between $55 \pm 4$ and $103 \pm 9 \mathrm{Ma}$, do not differ significantly from the previously published ages for the crystalline basement of the central southern Black Forest (20 \pm 2 and $83 \pm 12$ Ma; Timar-Geng et al. 2006). TimarGeng et al. (2006) reported a continuous cooling of the crystalline basement during the Cretaceous, Palaeogene, and the Early Eocene, based on apatite FT track length modelling, followed by short period of heating to temperatures of $\sim 120^{\circ} \mathrm{C}$ during Late Eocene to Oligocene. This significant heating period is contemporaneous to the initial rifting stage, independently constrained by subsidence in the URG (e.g. Hinsken et al. 2007). Our new data show evidence that this thermal overprint has also affected the Mesozoic sedimentary cover. Sample HD125, an Early Jurassic clay- to siltstone yielded an apatite FT central age $(93 \pm 20 \mathrm{Ma})$ younger than its deposition ages (178-184 Ma) suggesting that it has experienced partial annealing after deposition.

Yet a slightly modified thermal history form the one suggested generally for the study area must be proposed for the fault-related samples from the Kandern Fault Zone. The zircon FT ages (Fig. 5) of the fault-related samples HD128 $(109 \pm 17 \mathrm{Ma})$ and HD130 $(120 \pm 20 \mathrm{Ma})$ are slightly 
younger than the zircon FT ages from the southern Black Forest (this study, Timar-Geng et al. 2004, 2006). Although samples HD128 and HD130 from the Kandern Fault Zone overlap within $1 \sigma$ error interval with the young zircon FT ages determined in the central southern Black Forest (Timar-Geng et al. 2004, 2006), a tendency towards younger ages cannot be overlooked (Fig. 5).

More detailed information on the thermal evolution of the fault zone can be obtained by integrating the microstuctural observations of the cataclasites from the Kandern Fault Zone together with FT results.

The fracturing and cementation structures of quartz resembling bulging recrystallization in Cataclasite-I correspond to similar microstructures, which have been observed at the transition between brittle and crystal-plastic deformation in other natural rocks (Fitz Gerald and Stünitz 1993; Stipp et al. 2002a, b) For bulging recrystallization in quartz, temperatures above approximately $280 \pm 30^{\circ} \mathrm{C}$ at strain rates of $10^{-12} \mathrm{~s}^{-1}$ were inferred (Stipp et al. 2002a, b), whereas Trepmann and Stöckhert (2003) suggested seismic pulses at ambient temperatures of $300-350^{\circ} \mathrm{C}$. In any case, the deformation temperature of Cataclasite-I appears to have been lower than about $280-300^{\circ} \mathrm{C}$ because of the lack of pervasive crystal-plastic deformation microstructures. Biotite grains inside cemented clasts of Cataclasite-I were deformed by kinking and gliding. Laboratory experiments on granites under high strain rates $\left(10^{-4}\right.$ to $\left.10^{-6} \mathrm{~s}^{-1}\right)$ at $300^{\circ} \mathrm{C}$ indicated that biotite deforms by a combination of fracturing, gliding and kinking (Tullis and Yund 1977; Kato et al. 2003; Keulen et al. 2007). The observed glide and kinking in biotite is consistent with slightly elevated temperatures of deformation, as inferred for quartz, but still below $280^{\circ} \mathrm{C}$.

In Cataclasite-II, all minerals were deformed in a brittle manner. No evidence for aggregates of rounded quartz grains was formed. Biotite is always fractured. Mainly brittle behaviour has been observed for biotites that have been experimentally deformed at $180^{\circ} \mathrm{C}$ under strain rates of $10^{-4}$ to $10^{-6} \mathrm{~s}^{-1}$ (Kato et al. 2003). The transition from brittle to semi-brittle behaviour of biotite in natural fault zones is estimated at about $150^{\circ} \mathrm{C}$ by Lin (1999).

After the formation of Cataclasite-II silica-rich veins formed. Cataclasis led to enhanced permeability and a high grain surface area to grain volume ratio, which favoured the dissolution of silica. As silica is very insoluble and, therefore, very immobile at temperatures below approximately $70^{\circ} \mathrm{C}$ (e.g. Truesdell 1984), the temperature is assumed to have been higher than ca. $70^{\circ} \mathrm{C}$. Temperatures below $150^{\circ} \mathrm{C}$ are estimated for the formation of Cataclasite-II based on the veins, as well as quartz and biotite microstructures.

Cathodoluminescence investigations confirm the presence of two generations of cataclasites formed under different temperature conditions. Two phases of vein cementation are observed in quartz and K-feldspar. In Cataclasite-I, fragments are grown together with newly deposited luminescent material; Cataclasite-II veins are filled with non-luminescent material (Fig. 4). Material precipitated under higher temperatures is luminescent, but vein filling precipitated under diagenetic temperatures hardly show any luminescence (e.g. Ramseyer et al. 1992; Milliken and Laubach 2000).

The grain-size distribution of Cataclasite-II shows a $D$ value of 1.58. This value is close to the value measured for parts of the San Andreas Fault $(D=1.60$; Sammis et al. $1987)$, the Qin-Ling Mountain, China $(D=1.59$; Shao and Zou 1996), and the Nojima Fault Zone, Japan $(D=1.59$; Boullier et al. 2004; Keulen et al. 2008). Keulen et al. (2008) showed that for granitoid samples, experimentally deformed at a rate of $10^{-4} \mathrm{~s}^{-1}$, the $D$ values of 1.5 to 1.6 are the result of healing after heat treatment after deformation of the samples in presence of a fluid. The observed grain size distribution of Cataclasite-II in the Kandern Fault Zone is, therefore, most likely the result of healing of the cataclasite after deformation.

As outlined above, formation of Cataclasite-I occurred under higher temperatures (less than $280^{\circ} \mathrm{C}$ ) than Cataclasite-II (between 150 and $\sim 70^{\circ} \mathrm{C}$ ). If these syndeformational temperatures persisted long enough, full annealing of FT's in apatites of the fault-related samples will occur during the formation of Cataclasite-I and/or Cataclasite-II. Moreover, the temperature during the formation of Cataclasite-I was probably high enough to allow shortening of FT's in zircon for appropriate geological time spans.

Various scenarios for the formation of Cataclasite-I could be suggested based on the FT analysis and in particular the palaeo-temperatures determined by the microstructural analyses within the Kandern Fault Zone. First, during the Late Variscan emplacement of the Schlächtenhaus pluton (Schaltegger 2000), a high geothermal gradient deformation and associated fluid migration could have provided the necessary conditions to produce the observed microstructures and estimated temperatures. Second, the observed features could be explained by repeated hydrothermal activity related to tectonic reactivation of Variscan structures during the Late Jurassic (e.g. Wetzel and Allia 2003; Wetzel et al. 2003). We have observed repeated fracturing after intermittent healing within the cataclasites, which indicates reactivation of the faults within the Kandern Fault Zone.

Both scenarios are valid to explain the formation of Cataclasite-I in agreement with the regional thermal evolution. During both scenarios the reported thermal conditions caused complete resetting of the zircon FT ages. The observed tendency to relatively young zircon FT ages 
from the fault-related samples (HD128 $109 \pm 17 \mathrm{Ma}$ and HD130 $120 \pm 20 \mathrm{Ma}$ ) point to the presence of an additional heating event causing only partial annealing of FT's in zircon. Such a local event affecting the samples of the Kandern Fault Zone is suggested to occur in post-Jurassic times. The apatite FT single grain ages older than approximately $80 \mathrm{Ma}$ (Fig. 2) of the fault-related samples (HD128, HD129) suggest that they have not experienced temperatures higher than $120^{\circ} \mathrm{C}$ over a significantly long time after $80 \mathrm{Ma}$. Therefore, a local anomaly along the Kandern Fault Zone with temperature conditions corresponding to the ZPAZ should have occurred after the Jurassic reheating period and clearly before the possible occurrence of a thermal pulse related to the rifting in the URG ( $\leq 50$ My, e.g. Hinsken et al. 2007).

Unfortunately, there is no further geological evidence for such an event and the proposed timing. As it was mentioned already a huge depositional hiatus between Late Jurassic and Late Eocene mask the geological evolution of this period. Therefore, the presence of thermal-tectonic event responsible for the observed microstructures of $\mathrm{Ca}-$ taclasite-I and/or the younging of the zircon FT ages at this time seems to be very difficult to be proven.

The thermal conditions estimated by the microstuctures for the formation of Cataclasite-II are valid for annealing of FT's in apatite. Depending on the heating duration the FT's in apatite experienced total or partial annealing. Therefore, the exact time of Cataclasite-II formation is also difficult to be constrained. However, Cataclasite-II has to postdate the final cooling below about $180^{\circ} \mathrm{C}$, the lower boundary of the ZPAZ (Tagami 2005), and the formation of Cataclasite-I. The apatite FT ages of the fault-related samples do not differ from the known apatite FT ages of the whole Kandern area (Table 1; Figs. 2, 5). This suggests that the formation of Cataclasite-II should have occurred before or contemporary to the Late Oligocene to Miocene rifting during which temperatures not higher than $120^{\circ} \mathrm{C}$ within its rift shoulders have been reported (Timar-Geng et al. 2006). Otherwise, the temperatures estimated for the formation of Cataclasite-II has to cause apatite FT ages clearly younger than the observed of the fault related samples. Therefore, the maximum time range for the Catalasite-II formation is suggested between the Late Jurassic and the Late Oligocene.

However, a high fluid flow during and after the formation of Cataclasite-II is witnessed by the occurrence of silicate veins. Fluid fluxes can increase along the fault zones before, during or after earthquakes due to an enhanced permeability (e.g. Sibson 1990; Tokunaga 1999; Hill et al. 1993; Huang et al. 2004). Additionally, the $D$ values of the grain size distributions of Cataclasite-II suggest a deformation during a seismic event. Therefore, a formation related to an enhanced tectonic and hydrothermal activity during the URG rifting seems to be very probable. This suggests a formation age of Cataclasite-II between about 30 and $50 \mathrm{Ma}$.

\section{Conclusions}

In general, the new apatite and zircon FT data from the south-western Black Forest are in line with the thermal evolution described previously for the central southern Black Forest (Timar-Geng et al. 2004, 2006). The last regional heating event up to temperatures within the ZPAZ occurred during the Jurassic from when on regional cooling dominated. This cooling was interrupted by a last heating event of up to $120^{\circ} \mathrm{C}$, probably associated with the URG rifting during the Late Eocene to Early Oligocene.

The microstuctural analyses of cataclasites from the south-eastern part of the URG Main Border Fault clearly show that repeated tectonic reactivation, accompanied by hydrothermal fluid migration, have taken place after the Variscan orogeny. Two distinct periods of cataclasite formation under different thermal conditions are identified. The older one occurred at temperatures less than $280^{\circ} \mathrm{C}$ and the younger one below $150^{\circ} \mathrm{C}$.

Integration of the microstructural observations with the FT data leads to a limitation of possible formation ages and scenarios for these events. Cataclasite-I formation was most probably either related to the Variscan orogeny or contemporary with the enhanced thermal conditions during the Jurassic. The cause of the younging of zircon FT central ages of the samples from the Kandern Fault Zone remains unclear. An additional post-Jurassic event could be responsible for the local occurrence of high thermal conditions along the Kandern Fault Zone, possibly leading to the observed shift in the zircon FT ages.

Cataclasite-II, younger than Cataclasite-I, postdates the last Jurassic heating episode and was most probably related to the Late Eocene to Oligocene heating event associated with the rifting of the URG.

Acknowledgments This work is a contribution of the EUCORURGENT Project (Upper Rhine Graben, Evolution and NeoTectonics). It has been supported by the Swiss National Science Foundation (Project Nos. 21-57038.99 and 20-64567.01 to A. Wetzel). We gratefully thank James R. Mackenzie $\dagger$ for all his help; we will never forget him! A. Kounov, M. Tischler, F. Gaidies, T. Heijboer, E. Wosnitza and S. Kock are thanked for fruitful discussion, W. Tschudin for thin sections. R. Waite, L. Cartier and C. Seiler for sample preparation. K. Ramseyer (Univ. Bern) for the introduction into cathodoluminescence and the usage of his microscope. Central Microscope Centre of the University Basel for the use of their facilities. The authors would like to thank S. Hinsken for introduction into the local geology and K. Ustaszewski for providing structural data of the Kandern Fault Zone. Careful reviews with very useful suggestions of B. Ventura and U. Glasmacher improved an earlier version of this manuscript. 


\section{Appendix}

FT analytical details

Apatite and zircon grains were separated from each sample (4-6 kg rock material) using standard crushing, magnetic and heavy liquid techniques. The zircon samples were mounted in Teflon PFA ${ }^{\circledR}$, while the apatite samples were embedded in epoxy resin. After polishing, the apatites were etched for $40 \mathrm{~s}$ in $6.5 \% \mathrm{HNO}_{3}$ at $\sim 18^{\circ} \mathrm{C}$ and the zircons for $6-12 \mathrm{~h}$ in a eutectic-melt of $\mathrm{KOH}-\mathrm{NaOH}\left(220^{\circ} \mathrm{C}\right)$. Mica was used as an external detector and $\mathrm{CN}-5$ (apatite) and $\mathrm{CN}-1$ (zircon) standards as dosimeter glasses. Irradiation with thermal neutrons was carried out at the Australian Nuclear Science and Technology Organisation facility (ANSTO).

Mica detectors were etched in $40 \% \mathrm{HF}$ for $40 \mathrm{~min}$ at $\sim 18^{\circ} \mathrm{C}$. Tracks were counted at a magnification of $1,600 \times$ (dry) on a Zeiss Axioplan2 optical microscope with a computer-controlled motorised scanning stage, run by the program "FT-STAGE 3.11" (Dumitru 1993).

The FT-age determination followed the zeta calibration method (Hurford and Green 1983) with a zeta value of $380.67 \pm 10.58$ (Durango, CN-5) for apatite and $145 \pm 6.88$ (Fish Canyon Tuff, CN-1) for zircon. The FT ages and errors were calculated using the software Trackkey (version 4.1) (Dunkl 2002).

\section{References}

Berger JP, Reichenbacher B, Becker D, Grimm M, Grimm K, Picot L, Storni A, Pirkenseer C, Derer C, Schäfer A (2005a) Paleogeography of the Upper Rhine Graben (URG) and the Swiss Molasse Basin (SMB) from Eocene to Pliocene. Int J Earth Sci 94:697710. doi:10.1007/s00531-005-0475-2

Berger JP, Reichenbacher B, Becker D, Grimm M, Grimm K, Picot L, Storni A, Pirkenseer C, Schäfer A (2005b) Eocene-Pliocene time scale and stratigraphy of the Upper Rhine Graben (URG) and the Swiss Molasse Basin (SMB). Int J Earth Sci 94:711-731. doi: 10.1007/s00531-005-0479-y

Boullier AM, Fujimoto K, Ito H, Ohtani T, Keulen N, Fabbri O, Amitrano D, Dubois M, Pezard P (2004) Structural evolution of the Nojima Fault (Awaji Island, Japan) revisited from the GSJ drillhole at Hirabayashi. Earth Planets Space 56:1233-1240

Brandon MT, Roden-Tice MK, Garver JI (1998) Late Cenozoic exhumation of the Cascadia accretionary wedge in the Olympic Mountains, northwest Washington State. Geol Soc Am Bull 110:985-1009. doi:10.1130/0016-7606(1998)110<0985:LCEOTC $>2.3 . \mathrm{CO} ; 2$

Chantraine J, Autran A Cavelier C et al (1996) Carte géologique de la France à l'échelle du millionième, 6e édn. BRGM, Orléans

Dumitru TA (1993) A new computer-automated microscope stage system for fission-track analysis. Nucl Tracks Radiat Meas 21:575-580. doi:10.1016/1359-0189(93)90198-I

Dunkl I (2002) Trackkey; a Windows program for calculation and graphical presentation of fission track data. Comput Geosci 28(1):3-12. doi:10.1016/S0098-3004(01)00024-3
Duringer P (1988) Les conglomérates des bordures du rift cénozoïque rhénan. Dynamique sédimentaire et contrôle climatique (Unpublished These). L'Université Louis Pasteur, Strasbourg, pp 1-278

Eisbacher GH, Lüschen E, Wickert F (1989) Crustal-scale thrusting and extension in the Hercynian Schwarzwald and Vosges, Central Europe. Tectonics 8(1):1-21. doi:10.1029/TC00 8i001p00001

Echtler HP, Chauvet A (1992) Carboniferous convergence and subsequent crustal extension in the southern Schwarzwald (SW Germany). Geodin Acta 5(1-2):37-49

Ernst M, Hergesell G (1997) Geologische Karte von BadenWürrtemberg 1:25.000, BL. 8211, Kandern, Landesvermessungsamt, Stuttgart

Fitz Gerald JD, Stünitz H (1993) Deformation of granitoids at low metamorphic grade I. Reactions and grain size reduction. Tectonophysics 221:3-4

Galbraith RF (1988) Graphical display of estimates having differing standard errors. Technometrics 30:271-281. doi:10.2307/1270081

Galbraith RF (1990) The radial plot: graphical assessment of spread in ages. Nucl Tracks Radiat Meas 17:207-214. doi: 10.1016/1359-0189(90)90036-W

Galbraith RF, Laslett GM (1993) Statistical models for mixed fission track ages. Nucl Tracks Radiat Meas 21:459-470. doi: 10.1016/1359-0189(93)90185-C

Geyer OF, Gwinner MP (1991) Geologie von Baden-Württemberg. Schweizerbart, Stuttgart, p 482

Giersch C (2006) Thermohydrodraulik des kristallinen Grundgebirges am Beispiel des östlichen Oberrheingrabens. AGK Schriftenr 72:1-156

Gleadow AJW (1981) Fission track dating: what are the real alternatives. Nucl Tracks 5:3-14. doi:10.1016/0191-278X(81)90021-4

Gleadow AJW, Duddy IR (1981) A natural long-term track annealing experiment for apatite. Nucl Tracks 5:169-174. doi:10. 1016/0191-278X(81)90039-1

Green PF, Duddy IR, Gleadow AJW, Tingate PR, Laslett GM (1985) Fission Track annealing in apatite: track lengths measurements and the form of the Arrhenius plot. Nucl Tracks 10:323-328

Gürler B, Hauber L, Schwander M (1987) Die Geologie der Umgebung von Basel. Beit zur Geol. Karte Schweiz 160:1-33

Haas IO, Hoffmann CR (1929) Temperature gradient in Pechelbronn oil-bearing region, Lower Alsace: its determination and relation to oil reserves. Bull Am Ass Petrol Geol 13:1257-1273

Hann HP, Sawatzki G (2000) Neue Daten zur Tektonik des Südschwarzwaldes. Jber Mitt Oberrhein Geol Ver 82:363-376

Häring MO (2002) Sondierbohrung Otterbach, Basel. Der erste Schritt zur Entwicklung eines geothermischen Heiz-Kraftwerks nach dem Hot-Dry-Rock Verfahren. Bull angew Geol 7(1):19_ 30

Hill DP, Reasenberg PA, Michael AJ, Arabasz WJ, Beroza GC, Brune JN, Brumbaugh DS, Castro R, Davis SD, dePolo DM, Ellsworth WL, Gomberg JS, Harmsen SC, House L, Jackson SM, Johnston MJ, Jones LM, Keller R, Malone SD, Munguia L, Nava S, Pechmann JC, Sanford AR, Simpson RW, Smith RS, Stark MA, Stickney MC, Vidal A, Walter SR, Wong V, Zollweg JE (1993) Seismicity in the Western United States remotely triggered by the M 7.4 Landers, California, earthquake of June 28, 1992. Open-file Rep (US Geol Surv), pp 238-276

Hinsken S, Ustaszewski K, Wetzel A (2007) Graben-width controls synrift sedimentation: the Palaeogene southern Upper Rhine Graben as an example. Int J Earth Sci. doi:10.1007/ s00531-006-0162-y

Huang F, Jian C, Tang Y, Xu G, Deng Z, Chi G (2004) Response changes of some wells in the mainland subsurface fluid monitoring network of China, due to the September 21, 1999, Ms7. 6 Chi-Chi Earthquake. Tectonophysics 390:217-234. doi: 10.1016/j.tecto.2004.03.022 
Hurford AJ, Green PF (1983) The zeta age calibration of fission-track dating. Chem Geol 41(4):285-317

Hurford AJ (1990) International Union of Geological Sciences Subcommission on Geochronology recommendation for the standardization of fission track dating calibration and data reporting. Nucl Tracks Radiat Meas 17(3):233-236. doi: 10.1016/1359-0189(90)90040-5

Illies JH (1967) Development and tectonic pattern of the Rhinegraben. Abh Geologischen Landesamtes Baden-Wurttemberg 6:7-9

Jelinek AR, Bastos-Neto AC, Lelarge MLV, Soliani E Jr (1999) Apatite fission-track dating of fluorite ore veins from Santa Catarina state, Brasil: a complex hydrothermal evolution. J S Am Earth Sci 12:367-377. doi:10.1016/S0895-9811(99)00028-0

Kasuya M, Naeser CW (1988) The effect of alpha-damage on fissiontrack annealing in zircon. Nucl Tracks Radiat Meas 14(4):477480. doi:10.1016/1359-0189(88)90008-8

Kato A, Ohnaka M, Mochizuki H (2003) Constitutive properties for the shear failure of intact granite in seismogenic environments. J Geophys Res 108(B1). doi:10.1029/2001JB000791

Keulen N, Heilbronner R, Stünitz H, Boullier AM, Ito H (2007) Grain size distribution of gouge; a comparison between experimentally deformed granitoids and the Nojima Fault Zone. J Struct Geol 29(8):1282-1300. doi:10.1016/j.jsg.2007.04.003

Keulen N, Stünitz H, Heilbronner R (2008) Healing microstructures of experimental and natural fault gouge. J Geophys Res 113:B06205. doi:10.1029/2007JB005039

Lampe C, Person MA (2002) Advective cooling within sedimentary rift basins-application to the Upper Rhinegraben (Germany). Mar Pet Geol 19(3):361-375. doi:10.1016/S0264-8172(02)00022-3

Laubscher H (1987) Die tektonische Entwicklung der Nordschweiz. Eclogae Geol Helv 80(2):287-303

Lüders V (1994) Geochemische Untersuchungen an Gangmineralen aus dem Bergbaurevier Freiamt-Sexau und dem BadenweilerQuarzriff (Schwarzwald). Abh Geologischen Landesamtes Baden-Wurttemberg 14:173-190

Lin A (1999) S-C cataclasite in granitic rock. Tectonophysics 304:257-273. doi:10.1016/S0040-1951(99)00026-8

Metz R, Rein G (1957) Geologisch-petrographische Übersichtskarte des Südschwarzwaldes mit Erz- und Mineralgängen, 1:50000. Moritz Schauenburg Verlag, Lahr/Schwarzwald

Milliken KL, Laubach SE (2000) Brittle deformation in sandstone diagenesis as revealed by scanned cathodoluminescence imaging with application to characterization of fractured reservoirs. In: Pagel M, Barbin V, Blanc P, Ohnenstetter D (eds) Cathodoluminescence in geosciences. Springer, Berlin, pp 225-243

Naeser CW (1976) Fission-track dating. Open-file Rep (US Geol Surv), pp 76-190

Parry WT, Bunds MP, Bruhn RL, Hall CM, Murphy JM (2001) Mineralogy, 40Ar/39Ar dating and apatite fission track dating of rocks along the Castle Mountain fault, Alaska. Tectonophysics 337:149-172. doi:10.1016/S0040-1951(01)00117-2

Paul W (1955) Zur Morphogenese des Schwarzwaldes (I). Jh Geol Landesamt Baden-Württemberg 1:395-427

Person M, Garven G (1992) Hydrologic constraints on petroleum generation within continental rift basins; theory and application to the Rhine Graben. Am Assoc Pet Geol Bull 76(4):468-488

Ramseyer K, Fischer J, Matter A, Eberhardt P, Geiss J (1989) A cathodoluminescence microscope for low intensity luminescence. J Sediment Petrol 59:619-622

Ramseyer K, AlDahan AA, Collini B, Landström O (1992) Petrological modifications in granite rocks from the Siljan impact structure: evidence from cathodoluminescence. Tectonophysics 216:195-204. doi:10.1016/0040-1951(92)90166-4

Rahn MK, Brandon MT, Batt GE, Garver JI (2004) A zero-damage model for fission-track annealing in zircon. Am Mineral 89(4):473-484
Rybach L (2007) The geothermal conditions in the Rhine Graben-a summary. Bull für angewandte Geol 12(1):29-32

Sammis CG, King G, Biegel RL (1987) The Kinematics of Gouge Deformation. Pure Appl Geophys 125:777-812. doi:10.1007/ BF00878033

Schaltegger U (2000) U-Pb geochronology of the Southern Black Forest Batholith (Central Variscan Belt): timing of exhumation and granite emplacement. Int J Earth Sci 88:814-828. doi: $10.1007 / \mathrm{s} 005310050308$

Schellschmidt R, Clauser C (1996) The thermal regime of the Upper Rhine Graben and the anomaly at Soultz. Z Angew Geologie 42(1):40-44

Schnarrenberger K (1985) Erläuterungen zu Blatt 8211 KandernGeologische Karte 1:25.000 von Baden-Württemberg. Geologisches Landesamt Baden-Würrtemberg, Heidelberg/Stuttgart, pp 1-131

Schreiner A, Söll H, Wimmenauer W (1957) Über zwei neugefundene tertiäre Tuffschlote bei Feuerbach (Südbaden). Jh Geol Landesamt Baden-Wurttemberg 2:179-192

Schumacher ME (2002) Upper Rhine Graben: the role of pre-existing structures during rift evolution. Tectonics 21(1). doi:10.1029/ 2001TC900022

Shao SM, Zou JC (1996) Fractal research of fault gouge. Acta Seismol Sin 9(3):485-491. doi:10.1007/BF02650984

Sibson RH (1990) Faulting and fluid flow. In: Nesbitt BE (ed) Mac short course handbook series Vol 18. Short course on fluids in tectonically active portions of the continental crust. Mineralogical Association of Canada, Vancouver, pp 93-129

Sissingh W (1998) Comparative Tertiary stratigraphy of the Rhine Graben, Bresse Graben and Molasse Basin; correlation of Alpine Foreland events. Tectonophysics 300(1-4):249-284. doi: 10.1016/S0040-1951(98)00243-1

Stipp M, Stünitz H, Heilbronner R, Schmid SM (2002a) The eastern Tonale fault zone: a 'natural laboratory' for crystal plastic deformation of quartz over a temperature range from 250$700^{\circ} \mathrm{C}$. J Struct Geol 24:1861-1884. doi:10.1016/S0191-8141 (02)00035-4

Stipp M, Stünitz H, Heilbronner R, Schmid SM (2002b) Dynamic recrystallization of quartz: correlation between natural and experimental conditions. In: De Meer S et al (eds) Deformation mechanisms, rheology and tectonics: current status and future perspectives, vol 200. Geol Soc Spec Publ, London, pp 171190

Surma F, Geraud Y, Pourcelot L, Gauthier-Lafaye F, Clavaud JB, Zamora M, Lespinasse M, Cathelineau M (2003) Microstructures d'un gres affecte par une faille normale; anisotropie de connectivite et de permeabilite. Bull Soc Geol Fr 174(3):295303. doi: $10.2113 / 174.3 .295$

Tagami T, O'Sullivan PB (2005) Fundamentals of fission-track thermochronology. In: Reiners PW, Ehlers TA (eds) Lowtemperature thermochronology: techniques, interpretations, and applications. Rev Mineral Geochem 58, pp 19-47. doi:10.2138/ rmg.2005.58.2

Tagami T (2005) Zircon fission-track thermochronology and applications to fault studies. In: Reiners PW, Ehlers TA (2005) Lowtemperature thermochronology: techniques, interpretations, and applications. Rev Mineral Geochem 58, pp 95-122. doi:10.2138/ rmg.2005.58.4

Teichmüller M (1979) Die Diagenese der kohligen Substanzen in den Gesteinen des Tertiärs und Mesozoikums des mittleren Oberrhein-Grabens. In: Reiche E, Hilden HD (eds) Inkohlung und Geothermik; Beziehungen zwischen Inkohlung, Illit-Diagenese, Kohlenwasserstoff Führung und Geothermik. Fortschritte in der Geologie von Rheinland und Westfalen 27, pp 19-49

Timar-Geng Z, Fügenschuh B, Schaltegger U, Wetzel A (2004) The impact of the Jurassic hydrothermal activity on zircon fission 
track data from the southern Upper Rhine Graben area. Schweiz Mineral Petrogr Mitt 84:257-269

Timar-Geng Z, Fügenschuh B, Wetzel A, Dresmann H (2006) Lowtemperature thermochronology of the flanks of the southern Upper Rhine Graben. Int J Earth Sci 95(4):685-702. doi: 10.1007/s00531-005-0059-1

Timar-Geng Z, Henk A, Wetzel A (2008) The impact of convective heat transfer on the interpretation of fission-track data. In: Lisker F, Ventura B, Glasmacher U (eds) Thermochronological methods: from paleotemperature constraints to landscape evolution models. Geological Society, London (Special Publications, in press)

Todt W (1976) Zirkon-U/Pb-Alter des Marlsburg-Granites vom SüdSchwarzwald. N Jb Min H12:532-544

Thury M, Gautchi A, Mazurek M, Müller WH, Naef H, Pearson FJ, Vomvoris S, Wilson W (1994) Geology and hydrology of the crystalline basement of northern Switzerland. NAGRA Technischer Bericht 93-01:3-1-3-11

Tokunaga T (1999) Modeling of earthquake-induced hydrological changes and possible permeability enhancement due to the 17 January 1995 Kobe Earthquake, Japan. J Hydrol (Amst) 223:221-229. doi:10.1016/S0022-1694(99)00124-9

Trepmann CA, Stöckhert B (2003) Quartz microstructures developed during non-steady state plastic flow at rapidly decaying stress and strain rate. J Struct Geol 25(12):2035-2051. doi:10.1016/ S0191-8141(03)00073-7

Truesdell AH (1984) Chemical geothermometers for geothermal exploration. In: Henley RW, Truesdell AH, Barton PB Jr (eds) Fluid-mineral equilibria in hydrothermal systems. Reviews in economic geology. Society of Economic Geologists, Chelsea, pp 31-43

Tullis J, Yund RA (1977) Experimental deformation of dry Westerly Granite. J Geophys Res 82(36):5705-5718. doi:10.1029/ JB082i036p05705

Ustaszewski K, Schumacher ME, Schmid SM (2005) Simultaneous normal faulting and extensional flexuring during rifting; an example from the southernmost Upper Rhine Graben. Int J Earth Sci 94(4):680-696. doi:10.1007/s00531-004-0454-Z
Werner D, Doebl F (1974) Eine geothermische Karte des Rheingrabenuntergrundes. In: Illies JH, Fuchs K (eds) Approaches Taphrogenesis, Stuttgart, pp 182-191

Werner W, Franzke HJ (2001) Postvariszische bis neogene Bruchtektonik und Mineralisation im südlichen Zentralschwarzwald. Z Dtsch Geol Ges 152:405-437

Wetzel A, Allia V (2003) Der Opalinuston in der Nordschweiz: Lithologie und Ablagerungsgeschichte. Eclogae Geol Helv 96(3):451-469

Wetzel A, Allenbach R, Allia V (2003) Reactivated basement structures affecting the sedimentary facies in a tectonically "quiescent" epicontinental basin; an example from NW Switzerland. Sed Geol 157(1-2):153-172. doi:10.1016/S0037-0738 (02)00230-0

Wilser JL (1914) Die Rheintalflexur nördöstlich von Basel zwischen Lörrach und Kandern und ihr Hinterland. Mitt Bad Geol L- Anst 7(2):485-640

Wimmenauer W, Schreiner A (1990) Erläuterungen zu Blatt 8114, Feldberg. Geol Karte Baden-Württemberg 1:25 000, Stuttgart, p 134

Wirth G (1984) Kleintektonische Untersuchungen im Grund- und Deckgebirge des Südostschwarzwaldes (Baden-Würtemberg). Arb Inst Geol Paläont Univ Stuttgart, NF 78:85-136

Ziegler PA (1994) Cenozoic rift system of western and central Europe: an overview. Geol Mijnb 73:99-127

Ziegler PA, Dèzes P (2005) Evolution of the lithosphere in the area of the Rhine rift system. Int J Earth Sci 94(4):594-614. doi: 10.1007/s00531-005-0474-3

Ziegler PA, Dèzes P (2007) Cenozoic uplift of Variscan Massifs in the Alpine foreland: timing and controlling mechanisms. Global Planet Change 58(1-4):237-269. doi:10.1016/j.gloplacha.2006. 12.004

Zienert A (1986) Grundzüge der Grossformenentwicklung Süddeutschlands zwischen Oberrheinebene und Alpenvorland. Selbstverlag, Heidelberg, pp 1-160 